\title{
Orthotopic liver transplantation for Management of a Giant Liver Hemangioma: a case report and review of literature
}

\author{
Hesameddin Eghlimi, Peyman Arasteh and Nazanin Azade *(D)
}

\begin{abstract}
Background: Hepatic hemangioma $(\mathrm{HH})$ is the most common benign tumor of the liver. In special conditions such as rapidly growing tumors, persistent pain, hemorrhage and when pressure effect on adjacent organs exist treatment is indicated. Surgical management is the most common treatment for $\mathrm{HH}$.

Case presentation: A 38-year-old male patient was diagnosed with $\mathrm{HH}$ for 7 years. The initial presentation of the mass was progressive abdominal distention causing early satiety, gastro-esophageal reflux disease, vomiting, dysphagia and weight loss. Later, the patient developed bilateral lower extremity edema. Imaging with computed tomography (CT scan) showed a large mass measuring $32.4^{*} 26^{*} 3.1 \mathrm{~cm}$ which was considered unresectable. The patient underwent a deceased donor liver transplantation. The excised mass was $9 \mathrm{~kg}$. After nine days of hospitalization the patient was discharged in good condition. Three months later, the patient was admitted due to fever and cytomegalovirus infection for which he received intravenous ganciclovir and was discharged. In the latest follow-up the patient had no liver or kidney dysfunction eight months after the transplantation.
\end{abstract}

Conclusion: With appropriate patient selection, liver transplantation can be considered as a treatment option for patients with huge HHs which are life-threatening and surgically unresectable.

Keywords: Hepatic Hemangioma, Liver transplantation, Benign liver neoplasms, Cavernous Hemangioma

\section{Background}

Hepatic Hemangioma $(\mathrm{HH})$ is the most common benign tumor of the liver. The tumor has a vascular nature and is usually solitary and small in size. The majority of HHs originate from the right hepatic lobe. Classically $\mathrm{HHs}$ are not clinically symptomatic and are incidental findings in imaging studies [1]. No definite genetic background has been suggested for the occurrence of $\mathrm{HH}$; however few cases of familial hepatic hemangiomas have been described in literature [2]. A well-established gender disparity with female to male ration of $5: 1$ is reported for the tumor [3]. Estrogen therapy and

* Correspondence: nazaninazadeh91@gmail.com

Shiraz Transplant Research Center, Shiraz University of Medical Sciences,

Shiraz, Iran pregnancy are the major causes promoting tumor growth in HHs, highlighting the role of female sex hormones in the pathogenesis of the tumor [4]. Adulthood is the usual period of presentation, with the average age of diagnosis varying from 30 to 50 years old [5]. HH tumors are mostly asymptomatic; however larger tumors present with abdominal discomfort and rarely cause jaundice, high cardiac output heart failure, hemorrhage and consumptive coagulopathy, a syndrome known as Kasabach-Merritt syndrome (KMS). Treatment of $\mathrm{HH}$ is only indicated in special cases $[1,6]$. Herein, we present a case of a $9 \mathrm{~kg}$ giant $\mathrm{HH}$ that underwent liver transplantation and evaluate existing literature.

C The Author(s). 2020 Open Access This article is licensed under a Creative Commons Attribution 4.0 International License, which permits use, sharing, adaptation, distribution and reproduction in any medium or format, as long as you give appropriate credit to the original author(s) and the source, provide a link to the Creative Commons licence, and indicate if changes were made. The images or other third party material in this article are included in the article's Creative Commons licence, unless indicated otherwise in a credit line to the material. If material is not included in the article's Creative Commons licence and your intended use is not permitted by statutory regulation or exceeds the permitted use, you will need to obtain permission directly from the copyright holder. To view a copy of this licence, visit http://creativecommons.org/licenses/by/4.0/ The Creative Commons Public Domain Dedication waiver (http://creativecommons.org/publicdomain/zero/1.0/) applies to the data made available in this article, unless otherwise stated in a credit line to the data. 


\section{Case presentation}

A 38-year-old patient was under conservative follow-up for a huge $\mathrm{HH}$ for 7 years. At the time of presentation, the patient had noticed gradual abdominal distention and epigastric discomfort for which he sought medical consultation. He was previously healthy and had no significant past medical or family history of any significant disease. Imaging with ultrasonography and abdominal 4phase CT scan were in favor of a hemangioma probably originating from the fifth and eighth right liver lobe, initially measuring $12 * 10 * 1.5 \mathrm{~cm}$.

At the time of diagnosis, his management plan included a biannual follow-up of the mass via imaging studies including abdominal ultrasonography and magnetic resonance imaging (MRI). During the next 7 years the mass was growing in size and the patient complained of exacerbation of abdominal discomfort, early satiety, vomiting and bilateral lower extremity edema. Due to mass effect of the $\mathrm{HH}$, he developed disturbing gastroesophageal reflux disease causing significant weight loss and dysphagia to solid foods, for which an upper gastrointestinal tract endoscopy was performed. The study revealed severe esophagitis and stricture of the lower portion of the esophagus with hiatal hernia. The last abdominal MRI showed a heterogeneous solid mass measuring $32.4 * 26 * 3.1 \mathrm{~cm}$ in size originating from the right liver lobe. The mass had displaced the right kidney downwards and the right diaphragm upwards, however it had not caused any pressure effect on the intra or extra hepatic bile ducts. The IVC was also compressed, causing venous stasis in the lower extremities (Fig. 1).

Ultrasonography of the portal system showed pressure effect of the mass causing deviation of the portal vein and hepatic artery to the left sub-diaphragmatic aspect of the abdomen with mild portal hypertension and small amount of ascitic fluid. However, he had no esophageal varices reported in esophagoscopy. Despite the huge mass size, the patient did not develop KMS and had a relatively normal liver function test until the transplantation, which was as followed: AST $=45 \mathrm{IU} / \mathrm{L}$ (normal range: 5-42 IU/L), $\mathrm{ALT}=34 \mathrm{IU} / \mathrm{L}$ (normal range: 5-37 $\mathrm{IU} / \mathrm{L}$ ), ALP $=256 \mathrm{IU} / \mathrm{L}$ (normal range: 50-275 IU/L) with total and direct bilirubin of $0.9 \mathrm{mg} / \mathrm{DL}$ (normal range $0-1$ $\mathrm{mg} / \mathrm{DL}$ ) and $0.3 \mathrm{mg} / \mathrm{DL}$ (normal range: $0-0.35 \mathrm{mg} / \mathrm{DL}$ ); respectively. He also had a platelet count of 256.000 (normal range: $141.000-356.000)$ and prothrombin time of 15.6 (normal range: 11-12.5) seconds. His echocardiography was also normal with an ejection fraction of $55 \%$.

Later, due to patient's extreme discomfort and risk of rupture and hemorrhage, a multi-disciplinary team decided to put the patient on the liver transplant waiting list. After 12 months, the patient underwent whole organ liver transplantation using a cadaver graft. During laparotomy, numerous collateral abdominal veins and approximately $400 \mathrm{cc}$ of ascitic fluid were observed.

The native liver was dissected using a traditional hepatectomy technique and the estimated bleeding during hepatectomy was $1000 \mathrm{cc}$. Duct to duct anastomosis was done with $1000 \mathrm{cc}$ bleeding after reperfusion. Fluid transfusion during surgery included $2500 \mathrm{cc}$ of crystalloid fluid and $20 \mathrm{mg}$ of albumin before and after declamping. He also received a transfusion of 4 units of packed red blood cells during the operation. The surgery lasted for $330 \mathrm{~min}$ and the patient was transferred to the intensive care unit with no acute complication. The explanted liver weighed $9 \mathrm{~kg}$ (Fig. 2).

During pathologic examination, serial sections showed multiple infiltrative masses with spongy microcystic surface occupying the whole liver (Fig. 3a).

Microscopic examination revealed dilated vascular spaces, located between hepatocytes, lined by endothelial cells and containing red blood vessels. There was no significant atypia (Fig. 3b).

Patient was discharged after 9 days with an immunosuppressive regimen of Tacrolimus (Prograf $2 \mathrm{mg}$ $\mathrm{Q} 12 \mathrm{H}$ ) and Mycophenolate (Myfortic $360 \mathrm{mg}$ Q12H).

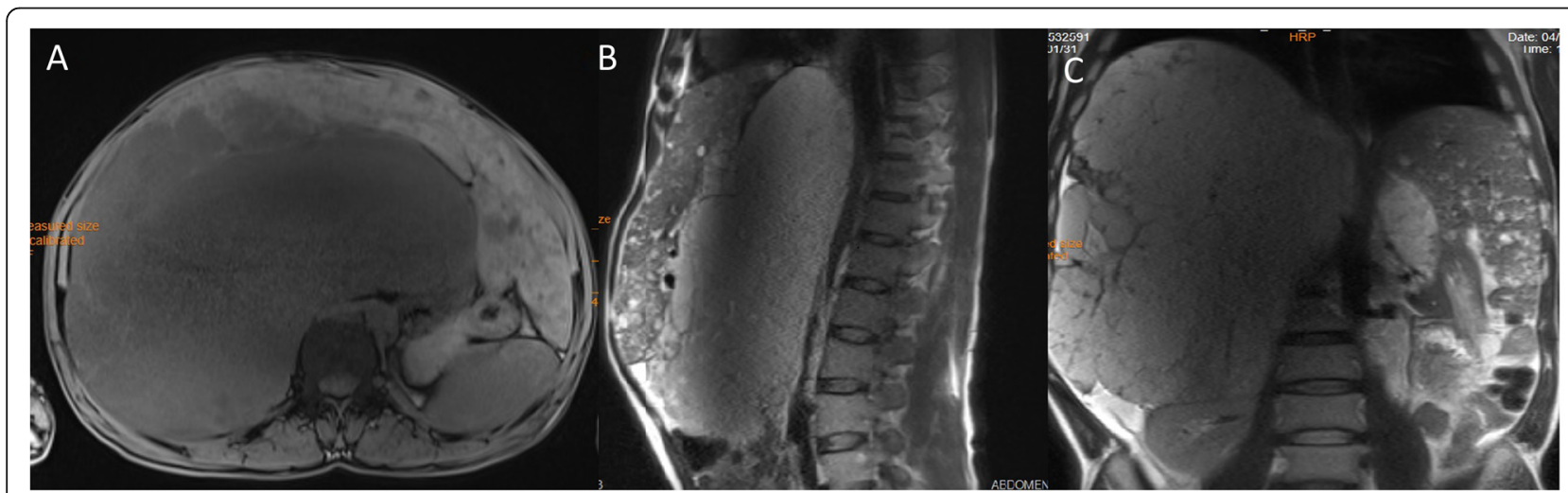

Fig. 1 T1-weighted abdominal MRI showing a huge heterogeneous mass originating from right liver lobe in axial, sagittal and coronal views (a, b and $\mathbf{c}$, respectively) with nodular discontinuous enhancement after gadolinium injection (b, c) 


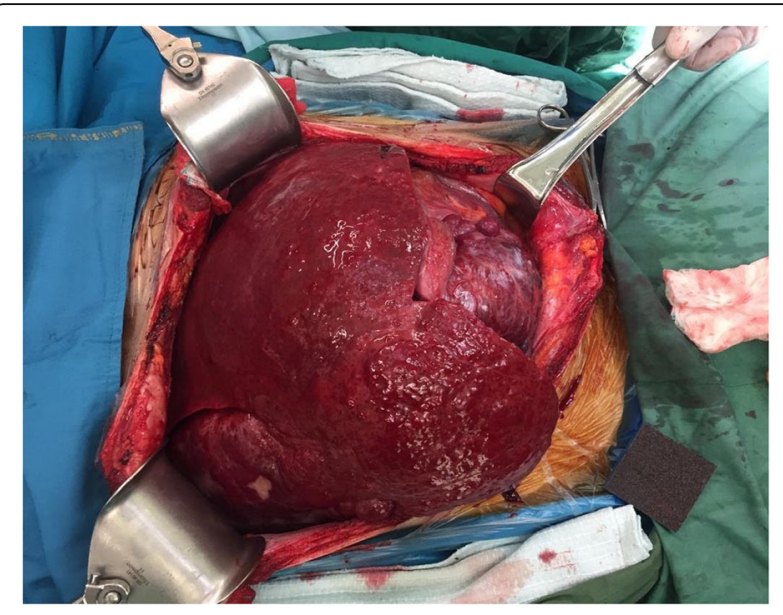

Fig. 2 Gross pathology of the native liver showing a huge inhomogeneous well-circumcised sub-capsular mass weighing 9 kgs which occupied the whole abdomen

Three months post-surgery, the patient was admitted with fever and had a positive PCR for cytomegalovirus. During admission the patient was given intravenous gancyclovir (Valcyte $350 \mathrm{mg}$ Q24H, 10 days) and was discharged after a 7 day admission period with good conditions.

\section{Discussion and conclusion}

Hepatic hemangioma $(\mathrm{HH})$ is a common benign liver neoplasm. Due to different prognosis and complications of liver masses, $\mathrm{HH}$ should be differentiated from other benign or malignant lesions using various imaging modalities and other diagnostic methods [7]. Most HHs remain asymptomatic during a persons' lifetime and usually do not have the potential for malignant transformation. Considering these, most $\mathrm{HHs}$ do not require medical intervention and annual or biannual imaging follow-up is sufficient in the majority of cases. Treatment is only indicated for rapidly growing tumors, persistent pain, hemorrhage and when pressure effect on adjacent organs and vessels exists, which may results in symptoms such as Budd-Chiari syndrome, jaundice and lower extremity edema. KMS is also an indication to seek treatment, the syndrome is characterized by thrombocytopenia, coagulopathy and microangiopathic hemolytic anemia [1]. Spontaneous or trauma induced bleeding from the tumor, is a rare but potentially fatal complication of $\mathrm{HH}$ which needs emergent laparotomy [6].

Up to this date, no medication has been proposed as a definite choice for medical treatment of HH. Some previous studies have reported promising results with medical management of $\mathrm{HHs}$ using bevacizumab, sorafenib, interferon and combination of sirulimus with high dose propranolol, however more studies are needed to support these findings [8-11].

In rare cases, patients with huge $\mathrm{HH}$ undergo liver transplantation. Indications for liver transplantation include huge masses compromising liver function, KMS and inoperable life threatening huge masses [12]. Up to this date and to the best of the authors' knowledge, 20 liver transplantation for huge $\mathrm{HH}$ have been reported in 15 studies, using both living and deceased donor liver transplantation [13-27]. The youngest patient was a 4 week old infant [15] and the oldest to have liver transplantation was 51 years old [27]. Most transplants have been done due to KMS $(n=9)$ [13-16, 20-22, 24, 25]. Other causes included diffuse mass or rapid growth with imminent rupture $(n=4)[19,21,23,26]$, respiratory distress $(n=4)[14,21,25,26]$, rupture $(n=2)[16,24]$, pain/discomfort $(n=3)[16,17]$ and bleeding $(n=1)$ [17]. A summary of existing literature is presented in Table 1.

Currently the most common treatment approach, especially with huge HHs is surgical intervention. Treatment options for huge cavernous $\mathrm{HHs}$ include surgical resection, transcatheter angiographic embolization

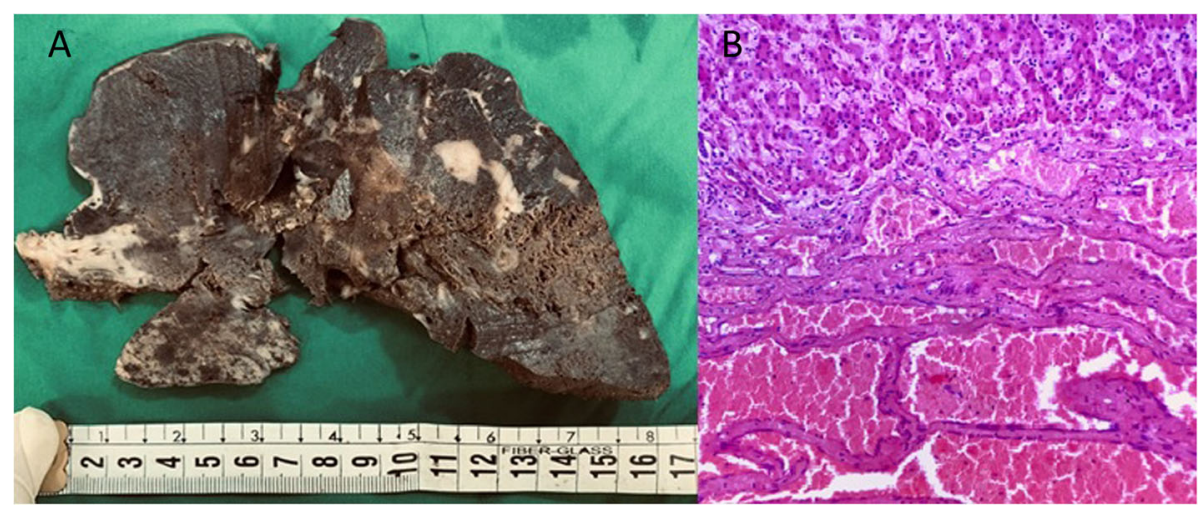

Fig. 3 Cut section of liver with multiple diffuse ill-defined spongy brown masses (a) and numerous dilated blood vessels adjacent to hepatocytes $(H \& E \times 200)(b)$ 
Table 1 Existing literature on liver transplantation in hepatic hemangioma

\begin{tabular}{|c|c|c|c|c|c|c|c|}
\hline $\begin{array}{l}\text { Report } \\
\text { no. }\end{array}$ & Author (year) & $\begin{array}{l}\text { Age (yrs)/ } \\
\text { sex }\end{array}$ & Graft Type & Follow-up & Cause of $\mathrm{Tx}$ & Complications & $\begin{array}{l}\text { Condition/ } \\
\text { cause of } \\
\text { death }\end{array}$ \\
\hline 1. & $\begin{array}{l}\text { Klompmaker et al. } \\
\text { (1989) [13] }\end{array}$ & 28/Male & Whole & 3 years & KMS & Uneventful & Alive \\
\hline 2. & Mora, et al. (1995) [14] & 42/Female & Whole & $\begin{array}{l}16 \text { days } \\
\text { postop }\end{array}$ & $\begin{array}{l}\text { KMS, respiratory } \\
\text { distress }\end{array}$ & NA & Alive \\
\hline 3. & Tepetes et al. (1995) [15] & 4wks/Male & Whole & 8 days & KMS & $\begin{array}{l}\text { Graft mal-function, intraventricular } \\
\text { hemorrhage }\end{array}$ & $\begin{array}{l}\text { Died, graft } \\
\text { mal-function }\end{array}$ \\
\hline 4. & Brouwers et al. (1997) [16] & NM & Whole & $\begin{array}{l}\text { 1. } 1 \text { month } \\
\text { 2. } 1 \text { year } \\
\text { 3. } 4 \text { years } \\
\text { 4. } 9 \text { years }\end{array}$ & $\begin{array}{l}\text { Pain }(n=2) \\
\text { rupture }(n=1) \\
\text { KMS }(n=1)\end{array}$ & $\begin{array}{l}\text { 1. Rejection, bile leakage \& pleural } \\
\text { effusion; 2. cytomegalovirus pneumonia, } \\
\text { duodenal ulcer, steroid diabetes, peripheral } \\
\text { nerve palsy \& Strongyloides stercoralis } \\
\text { infection; 3. uneventful }\end{array}$ & $\begin{array}{l}\text { 1. died Others } \\
\text { alive }\end{array}$ \\
\hline 5. & Chui et al. (1996) [17] & $\begin{array}{l}\text { 1. } 33 / \\
\text { Female } \\
\text { 2. } 43 / \\
\text { Female }\end{array}$ & Whole & $\begin{array}{l}\text { 1. } 18 \text { months } \\
\text { 2. } 14 \text { months }\end{array}$ & $\begin{array}{l}\text { 1. Bleeding } \\
\text { 2. Abdominal } \\
\text { discomfort }\end{array}$ & $\begin{array}{l}\text { 1. Massive hemorrhage during surgery, } \\
\text { ischemic graft with malfunction, acute } \\
\text { renal failure, second transplantation was } \\
\text { done; } 2 \text {. Uneventful }\end{array}$ & Both alive \\
\hline 6. & Longeville et al. (1997) [18] & 47/Male & Whole & 12 months & KMS & Post-transplantation internal hemorrhage & Alive \\
\hline 7. & Russo et al. (1997) [19] & 43/Female & Whole & $\begin{array}{l}14 \text { days } \\
\text { postop }\end{array}$ & Huge mass & NA & Alive \\
\hline 8. & $\begin{array}{l}\text { Kumashiro, et al. (2002) } \\
\text { [20] }\end{array}$ & 48/Female & $\begin{array}{l}\text { Posterior } \\
\text { lobe }\end{array}$ & $\begin{array}{l}15 \text { days } \\
\text { postop }\end{array}$ & $\begin{array}{l}\text { KMS, acute liver } \\
\text { failure }\end{array}$ & $\begin{array}{l}\text { Massive hemorrhage during operation due } \\
\text { to KMS, uneventful post-operation course }\end{array}$ & Alive \\
\hline 9. & Ferraz et al. (2004) [21] & 28/Female & Whole & 30 months & $\begin{array}{l}\text { KMS, respiratory } \\
\text { distress, huge } \\
\text { mass size }\end{array}$ & $\begin{array}{l}\text { One episode of acute rejection treated } \\
\text { with corticosteroid pulse }\end{array}$ & Alive \\
\hline 10. & Meguro et al. (2008) [22] & 45/Female & Left Lobe & 10 months & KMS & $\begin{array}{l}\text { Massive hemorrhage during operation, } \\
\text { acute rejection and small for size graft } \\
\text { syndrome, sepsis }\end{array}$ & Alive \\
\hline 11. & Zhong et al. (2014) [23] & 27/Female & Right lobe & 50 months & Huge mass & Two episodes of acute rejection & Alive \\
\hline 12. & Vagefi et al. (2011) [24] & 39/Female & Whole & NM & Rupture, KMS & Uneventful & Alive \\
\hline 13. & Yildiz et al. (2014) [25] & 44/Female & Whole & 1 month & $\begin{array}{l}\text { KMS, respiratory } \\
\text { distress }\end{array}$ & Uneventful & Alive \\
\hline 14. & Lange et al. (2015) [26] & 46/Female & Whole & 7 wks & $\begin{array}{l}\text { Huge mass causing } \\
\text { portal vein thrombosis, } \\
\text { ascites, DVT \& PTE }\end{array}$ & Uneventful & Alive \\
\hline 15. & Lee et al. (2017) [27] & 51/Female & $\begin{array}{l}\text { Modified } \\
\text { Right Lobe }\end{array}$ & 16 months & Rapid Growth & Uneventful & Alive \\
\hline
\end{tabular}

KMS Kasabach-Merritt Syndrome; POSTOP Postoperative; TAE Transcatheter angiographic embolization; NM Not mentioned; NA Not accessible manuscript; DVT Deep vein thrombosis; PTE Pulmonary thromboembolism; TX transplantation

(TAE), radiofrequency ablation, radiotherapy and in some cases orthotopic liver transplantation, as discussed earlier [1]. Minimally invasive techniques have been more frequently applied in recent years. The TAE method is done via catheterization of femoral artery and getting access to the hepatic artery to discover the tumor's feeding arteries. The feeding arteries are then embolized by using an embolic agent. Arterial embolization is usually left for tumors with a definite arterial supply and is usually indicated prior to surgical resection of inoperable lesions to reduce the tumor's size, facilitating the surgery [28]. Successful treatment of $\mathrm{HH}$ with TAE without surgery has also been reported [29]. Radiofrequency ablation uses high frequency current passing through an electrode which creates a small area of heat targeting the lesion. This method is either applied percutaneously or via laparoscopy and laparotomy. For most cases, significant symptom relief is achieved by RF-ablation. Due to difficult application of radiofrequency ablation technique for lesions larger than $10 \mathrm{~cm}$, patients with larger $\mathrm{HH}$ tumors do not efficiently benefit from this method [30,31]. Radiotherapy is a less frequently applied method for management of $\mathrm{HH}$ [32].

Surgical treatment of $\mathrm{HH}$ is considered for patients with severe symptoms affecting lifestyle, those suspicious of malignancy and huge tumors as they have an increased risk of rupture and bleeding [6]. Yet the optimal surgical approach still remains to be controversial. Surgeons may consider either segmental resection or enucleation of the tumor based on the location of the lesion. One meta-analysis conducted in 2016 reported that tumor tissue removal by both techniques can be safe 
and efficient; however due to decreased amount of intraoperative bleeding and a better preservation of normal hepatic tissue the enucleation method is the preferred surgical procedure [33].

\section{Conclusion}

With appropriate patient selection, liver transplantation can be considered as a treatment option for patients with huge hemangiomas of the liver when other treatment options have failed or are not indicated.

\section{Abbreviations}

CT scan: Computed tomography scan; HH: Hepatic hemangioma;

KMS: Kasabach-meritt syndrome; MRI: Magnetic resonance imaging;

TAE: Transcatheter angiographic embolization

\section{Acknowledgements}

Not applicable.

\section{Authors' contributions}

HE was the lead surgeon in the transplantation process. NA conceived the study and wrote the manuscript. PA and HE assisted in the preparation of the manuscript. All authors critically reviewed the manuscript and approved the final version of the manuscript and agreed to be accountable for all aspects of the work in ensuring that questions related to the accuracy or integrity of any part of the work are appropriately investigated and resolved.

\section{Funding}

No funding was applied for this study.

\section{Availability of data and materials}

Not applicable.

\section{Ethics approval and consent to participate}

The study involving a human participant to report was approved by the ethics committee of the department of Transplantation at Shiraz University of Medical Sciences. Written consent was obtained from the patient.

\section{Consent for publication}

Written informed consent was obtained from the patient for publication of this case report and accompanying images. A copy of the written consent is available for review by the Editor of this journal.

\section{Competing interests}

The authors declare no conflict of interest.

Received: 1 April 2020 Accepted: 16 June 2020

Published online: 29 June 2020

\section{References}

1. Bajenaru N, Balaban V, Săvulescu F, Campeanu I, Patrascu T. Hepatic hemangioma -review. J Med Life. 2015;8(Spec Issue):4-11.

2. Moser C, Hany A, Spiegel R. Familial giant hemangiomas of the liver. Study of a family and review of the literature. Praxis. 1998;87(14):461-8.

3. Henson SW Jr, Gray HK, Dockety MB. Benign tumors of the liver. Surg Gynecol Obstet. 1956;103:327-31.

4. Van Malenstein H, Maleux G, Monbaliu D, Verslype C, Komuta M, Roskams T, et al. Giant liver hemangioma: the role of female sex hormones and treatment. Eur J Gastroenterol Hepatol. 2011;23:438-43.

5. Gandolfi L, Leo P, Solmi L, Vitelli E, Verros G, Colecchia A. Natural history of hepatic haemangiomas: clinical and ultra-sound study. Gut. 1991;32(6):67780 .

6. Toro A, Mahfouz AE, Ardiri A, Malaguarnera M, Malaguarnera G, Loria F, et al. What is changing in indications and treatment of hepatic hemangiomas? A review. Ann Hepatol. 2014;13(4):327-39.

7. Bahirwani R, Reddy KR. Review article: the evaluation of solitary liver masses. Aliment Pharmacol Ther. 2008;28(8):953-65.
8. Mahajan D, Miller C, Hirose K, McCullough A, Yerian L. Incidental reduction in the size of liver hemangioma following use of VEGF inhibitor bevacizumab. J Hepatol. 2008;49(5):867-70.

9. Yamashita S, Okita K, Harada K, Hirano A, Kimura T, Kato A, Okita K. Giant cavernous hepatic hemangioma shrunk by use of sorafenib. Clin J Gastroenterol. 2013;6(1):55-62.

10. Ezekowitz RAB, Mulliken JB, Folkman J. Interferon a2A therapy for 'lifethreatening' hemangiomas in infancy. N Engl J Med. 1992;326(22):1456-63.

11. Warren $D$, Diaz L, Levy M. Diffuse hepatic hemangiomas successfully treated using sirolimus and high-dose propranolol. Pediatr Dermatol. 2017;34:e286-7.

12. Stringer MD. The role of liver transplantation in the management of pediatric liver tumours. Ann R Coll Surg Engl. 2007;89(1):12-21.

13. Klompmaker IJ, Sloof MJ, van der Meer J, de Jong GM, de Bruijn KM, Bams $J$. Orthotopic liver transplantation in a patient with a giant cavernous hemangioma of the liver and Kasabach-Merritt syndrome. Transplantation. 1989;48(1):149-51

14. Mora A, Cortés C, Roigé J, Noguer M, Camps MA, Margarit C. Orthotopic liver transplant for giant cavernous hemangioma and Kasabach-Merritt syndrome. Rev Esp Anestesiol Reanim. 1995;42(2):71-4.

15. Tepetes K, Selby R, Webb M, Madariaga JR, Iwatsuki S, Starzl TE. Orthotopic liver transplantation for benign hepatic neoplasms. Arch Surg. 1995;130(2): 153-6.

16. Brouwers MA, Peeters PM, de Jong KP, Haagsma EB, Klompmaker IJ, Bijleveld CM, et al. Surgical treatment of giant haemangioma of the liver. $\mathrm{Br}$ J Surg. 1997:84(3):314-6.

17. Chui AK, Vass J, McCaughan GW, Sheil AG. Giant cavernous haemangioma: a rare indication for liver transplantation. Aust N Z J Surg. 1996;66(2):122-4.

18. Longeville JH, de la Hall P, Dolan P, Holt AW, Lillie PE, Williams JA, et al. Treatment of a giant haemangioma of the liver with Kasabach-Merritt syndrome by orthotopic liver transplant. HPB Surg. 1997;10(3):159-62.

19. Russo MW, Johnson MW, Fair JH, Brown RS. Jr Orthotopic liver transplantation for giant hepatic hemangioma. Am J Gastroenterol. 1997; 92(10):1940-1.

20. Kumashiro Y, Kasahara M, Nomoto K, Kawai M, Sasaki K, Kiuchi T, et al. Living donor liver transplantation for giant hepatic hemangioma with Kasabach-Merritt syndrome with a posterior segment graft. Liver Transpl. 2002:8(8):721-4.

21. Ferraz AA, Sette MJ, Maia M, Lopes EP, Godoy MM, Petribú AT, et al. Liver transplant for the treatment of giant hepatic hemangioma. Liver Transpl. 2004;10(11):1436-7.

22. Meguro M, Soejima Y, Taketomi A, Ikegami T, Yamashita Y, Harada N, et al. Living donor liver transplantation in a patient with giant hepatic hemangioma complicated by Kasabach-Merritt syndrome: report of a case. Surg Today. 2008;38(5):463-8

23. Zhong L, Men TY, Yang GD, Gu Y, Chen G, Xing TH, et al. Case report: living donor liver transplantation for giant hepatic hemangioma using a right lobe graft without the middle hepatic vein. World J Surg Oncol. 2014;12(1):83.

24. Vagefi PA, Klein I, Gelb B, Hameed B, Moff SL, Simko JP, et al. Emergent orthotopic liver transplantation for hemorrhage from a giant cavernous hepatic hemangioma: case report and review. J Gastrointest Surg. 2011; 15(1):209-14.

25. Yildiz S, Kantarci M, Kizrak Y. Cadaveric liver transplantation for a giant mass. Gastroenterology. 2014;146:e10-1.

26. Lange UG, Bucher JN, Schoenberg MB, Benzing C, Schmelzle M, Gradistanac T, et al. Orthotopic liver transplantation for giant liver haemangioma: a case report. World J Transplant. 2015;5(4):354-9.

27. Lee $\mathrm{JH}$, Yoon CJ, Kim YH, Han H-S, Cho JY, Kim H, et al. Living-donor liver transplantation for giant hepatic hemangioma with diffuse hemangiomatosis in an adult: a case report. Clin Mol Hepatol. 2018;24(2):163.

28. Lupinacci RM, Szejnfedld D, Farah JF. Spontaneous rupture of a giant hepatic hemangioma. Sequential treatment with preoperative transcatheter arterial embolization and conservative hepatectomy. II giornale di chirurgia. 2011:32(11/12):469-72

29. Sun $\mathrm{JH}$, Nie $\mathrm{CH}$, Zhang $\mathrm{YL}$, et al. Transcatheter arterial embolization alone for giant hepatic hemangioma. PLoS One. 2015;10:e0135158.

30. GAO J, Ke S, Ding XM, Zhou YM, Qian XJ, Sun WB. Radiofrequency ablation for large hepatic hemangiomas. Initial experience and lessons. Surgery. 2012;153(1):78-85

31. Ji J, Gao J, Zhao L, Tu J, Song J, Sun W. Computed tomography-guided radiofrequency ablation following transcatheter arterial embolization in 
treatment of large hepatic hemangiomas. Medicine (Baltimore). 2016;95: e3402.

32. Gaspar L, Mascarenhas F, da Costa MS, Dias JS, Afonso JG, Silvestre ME. Radiation therapy in the unresectable cavernous hemangioma of the liver. Radiother Oncol. 1993;29(1):45-50.

33. Liu Y, Wei X, Wang K, Shan Q, Dai H, Xie H, Zhou L, Xu X, Zheng S.

Enucleation versus anatomic resection for Giant hepatic Hemangioma: a meta-analysis. Gastrointest Tumors. 2017;3(3-4):153-62.

\section{Publisher's Note}

Springer Nature remains neutral with regard to jurisdictional claims in published maps and institutional affiliations.

Ready to submit your research? Choose BMC and benefit from:

- fast, convenient online submission

- thorough peer review by experienced researchers in your field

- rapid publication on acceptance

- support for research data, including large and complex data types

- gold Open Access which fosters wider collaboration and increased citations

- maximum visibility for your research: over $100 \mathrm{M}$ website views per year

At BMC, research is always in progress.

Learn more biomedcentral.com/submissions 